\title{
PERUBAHAN HEMODINAMIKA PADA PASIEN YANG DILAKUKAN TERAPI HEMODIALISA DI RUANG HEMODIALISA RSUD Dr. MOEWARDI
}

\author{
Endah Dwi Maharsi, Hartono \\ Kementerian Kesehatan Politeknik Kesehatan Surakarta Jurusan Keperawatan
}

\begin{abstract}
Hemodynamic, Hemodyalisis. According to calculation of Pernefri on 2013, there are about 19.621 chronic renal failure patients which they need routine hemodialysis, over of 53\% of patients is under 54 years old. Recently, hemodialysis treatment get rapidly developing, but there are many health problem on patients when they get hemodialysis treatment. Patients often get some complication such as hemodynamic problem. The purpose of this research is to 1) to discribe the characteristics of the gender, age 2) to discribe the hemodynamic (sistole, diastole, MAP, RR, HR) of pre and post hemodialysis 3) to analize the hemodynamic changes pre and post hempdyalisis treatment. This type of research is quasy experiment with one group pretest - posttest design. The results of the research is there are hemodynamic changes in patients done hemodyalisis at the hemodialysis unit in Dr. Moewardi Hospital of Surakarta. This is proven by testing paired samples $t$-test (systole, MAP, HR) which obtained the value of $p<$ 0,05 and wilcoxon test (diastole, RR) which obtained the value of $p<0,05$. According to the test of paired samples t-test and Wilcoxon test if $p<0,05$, then the provision of therapy hemodialysis influential to changes in blood pressure. Conclusion. There is hemodynamic changes in patient done hemodyalisis at the hemodialysis unit dr.Moewardi Hospital.
\end{abstract}

Keywords: Hemodynamic, Hemodyalisis

Abstrak: Hemodialisa, Hemodinamik. Berdasarkan data tahunan dari
Perhimpunan Nefrologi Indonesia (Pernefri) tahun 2013, terdapat dari sekitar
19.621 pasien penderita gagal ginjal terminal yang membutuhkan hemodialisa
rutin, lebih dari 53\%-nya berusia dibawah 54 tahun. Tindakan HD saat ini
mengalami perkembangan yang cukup pesat, namun masih banyak penderita
mengalami masalah medis saat menjalani HD. Komplikasi yang sering terjadi
pada penderita yang menjalani HD adalah gangguan hemodinamik. Tujuan
penelitian ini adalah 1) mendiskripsikan karakteristik jenis kelamin dan usia 2)
mendiskripsikan status hemodinamik (MAP, RR, HR) pre dan post hemodialisa 3)
menganalisa perubahan hemodinamik pasien yang dilakukan terapi hemodialisa.
Jenis penelitian ini adalah quasi eksperiment dengan rancangan one group pretest-
posttest design. Hasil penelitian ini adalah ada perubahan hemodinamik pada
psien yang dilakukan terapi hemodialisa di ruang hemodialisa. Hal ini dibuktikan
dengan uji paired sampel t-test ( MAP dan HR) yang mana diperoleh nilai p $<$
0,05 dan uji Wilcoxon ( RR) dengan nilai p< 0,05 . Menurut uji paired sampel $t$ -
test dan uji wilcoxon jika p <0,05 maka ada perubahan hemodinamik pasien yang
dilakukan terapi hemodialisa. Kesimpulan pada penelitian ini adalah ada 
perubahan hemodinamik pada pasien yang dilakukan terapi henodialisa di ruang hemodialisa RSUD Dr. Moewardi.

Kata Kunci : Hemodialisa, Hemodinamik

\section{PENDAHULUAN}

Indonesia sebagai salah satu negara dengan jumlah penduduk terbesar di dunia masih menghadapi berbagai permasalahan kesehatan yang cukup pelik. Berdasarkan perkiraan WHO pada tahun 2012, angka harapan hidup penduduk Indonesia mencapai 71 tahun, dan pada tahun yang sama WHO memperkirakan angka kematian yang disebabkan oleh penyakit kronis di Indonesia mencapai 54\% dari seluruh penyebab kematian, melebihi angka kematian yang disebabkan karena penyakit menular dan kecelakaan. Salah satu penyakit kronis yang angka kejadiannya diperkirakan meningkat setiap tahunnya adalah penyakit gagal ginjal kronis (Sundara Y.T, 2014).

Menurut Grassman, dkk (2005), pada akhir tahun 2004 terdapat 1.783.000 penduduk dunia yang menjalani perawatan ginjal akibat gagal ginjal kronik, diantaranya $77 \%$ dengan cuci darah dan $23 \%$ dengan transplantasi ginjal. Sementara itu berdasarkan data tahunan dari Perhimpunan Nefrologi Indonesia (Pernefri) tahun 2013, terdapat dari sekitar 19.621 pasien penderita gagal ginjal terminal yang membutuhkan hemodialisa rutin, lebih dari 53\%-nya berusia dibawah 54 tahun. Data-data tersebut didapatkan dari kurang lebih 244 fasilitas hemodialisa di Indonesia yang sayangnya tidak dapat diakses oleh seluruh penderita gagal ginjal kronis dengan berbagai alasan. Hal ini berarti bahwa angka kejadian gagal ginjal kronis di masyarakat yang sebenarnya jauh lebih besar (Sundara Y.T, 2014).

Tindakan HD saat ini mengalami perkembangan yang cukup pesat, namun masih banyak penderita mengalami masalah medis saat menjalani HD. Komplikasi yang sering terjadi pada penderita yang menjalani HD adalah gangguan hemodinamik (Landry dan Oliver, 2006).

Menurut IRR (Indonesian

Renal Registry) (2013), dilaporkan bahwa penyebab kematian pasien hemodialisa di Indonesia paling banyak adalah karena gangguan kardiovaskuler yaitu sebanyak 826 pasien.

Penyakit kardiovaskuler merupakan faktor risiko penyebab kematian akibat penyakit gagal ginjal kronis, diperkirakan 10- 30 kali lebih tinggi pada klien hemodialysis daripada di populasi umum. Hipertensi merupakan salah satu penyakit kardiovaskuler yang sering menyebabkan mortalitas pada klien gagal ginjal kronis yang menjalani hemodialisis (Sukandar, 2006).

Tujuan dari penelitian ini adalah Untuk mengetahui perubahan hemodinamik pada pasien yang dilakukan terapi hemodialisa di ruang hemodialisa RSUD Dr. Moewardi Surakarta tahun 2016.

\section{METODE PENELITIAN}

Jenis penelitian ini termasuk dalam jenis penelitian quasy eksperiment dengan rancangan One Group Pretest-Postest Design, rancangan ini tidak ada kelompok pembanding (kontrol). Populasi pada 
penelitian ini adalah pasien yang menjalani terapi hemodialisa seminggu 2 kali di ruang hemodialisa RSUD Dr. Moewardi Surakarta pada bulan April tahun 2016. Berdasarkan studi pendahuluan yang dilakukan pada bulan April 2016, populasi pasien yang menjalani hemodialisa 2 kali seminggu sebanyak 129 pasien. Berdasarkan rumus, sampel yang akan diambil peneliti sebanyak 56 pasien yang memenuhi kriteria inklusi dan eksklusi.

\section{HASIL PENELITIAN}

1. Hasil Penelitian

a. Jenis Kelamin

Tabel 1

Jenis Kelamin Responden

\begin{tabular}{lll}
\hline Jenis Kelamin & Jumlah & $\begin{array}{l}\text { Prosentase } \\
(\%)\end{array}$ \\
\hline Laki-laki & 31 & $55.4 \%$ \\
Perempuan & 25 & $44.6 \%$ \\
Total & 56 & $100 \%$ \\
\hline
\end{tabular}

Dari tabel diatas dapat dapat diketahui bahwa laki- laki lebih banyak dibandingkan dengan perempuan dengan 31 responden $(55,4 \%)$.

b. Usia

Tabel 2

Usia Responden

\begin{tabular}{|c|c|c|c|}
\hline Umur & & Jumlah & $\begin{array}{l}\text { Prosentase } \\
(\%)\end{array}$ \\
\hline $\begin{array}{l}\text { Remaja } \\
\text { tahun) }\end{array}$ & $(17-25$ & 0 & $0 \%$ \\
\hline $\begin{array}{l}\text { Dewasa } \\
\text { tahun) }\end{array}$ & $(26-45$ & 18 & $32,1 \%$ \\
\hline $\begin{array}{l}\text { Lansia } \\
\text { tahun) }\end{array}$ & (> 45 & 38 & $67,9 \%$ \\
\hline Total & & & $100 \%$ \\
\hline
\end{tabular}

Dari tabel diatas dapat diketahui bahwa usia paling banyak dari responden yang menderita gagal ginjal kronik terdapat pada lansia $(>45$ tahun), yaitu sebanyak 38 responden $(67,9 \%)$. c. Nilai Hemodinamik Pre dan Post Hemodialisa

1) MAP

\section{Tabel 3}

MAP Pre dan Post Hemodialisa

\begin{tabular}{lll}
\hline & N & Mean \\
\hline Pre HD & 56 & 97,09 \\
Post HD & 56 & 106,48 \\
\hline
\end{tabular}

Dari tabel diatas dapat diketahui bahwa nilai MAP mengalami peningkatan. Hal itu dilihat dari nilai rata- rata MAP.

2) HR (Heart Rate)

Tabel 4

\section{HR Pre dan Post Hemodialisa}

\begin{tabular}{lll}
\hline & N & Mean \\
\hline HR Pre HD & 56 & 91,25 \\
HR Post HD & 56 & 90,80 \\
\hline
\end{tabular}

Dari tabel diatas dapat diketahui bahwa nilai HR mengalami penurunan. Hal itu dilihat dari nilai rata- rata HR.

3) RR (Respiratory Rate)

Tabel 5

RR Pre dan Post Hemodialisa

\begin{tabular}{lcc}
\hline & N & Mean \\
\hline RR Pre HD & 56 & 22,38 \\
\hline RR Post HD & 56 & 21,14 \\
\hline
\end{tabular}

d. Perubahan Hemodinamik

Pengolahan data yang digunakan pada penelitian ini adalah uji paired sample $t$ test.Uji Paired sample t-test digunakan untuk membandingkan hemodinamik (MAP, respiratory rate, heart rate) pre dan post pemberian tindakan hemodialisa. Uji paired sample $t$ test termasuk dalam uji statistik parametrik dengan syarat merupakan variabel numerik dan data berdistribusi normal. Jika tidak memenuhi syarat, maka digunakan uji alternatifnya, yaitu uji Wilcoxon (uji nonparametrik). Pada penelitian ini yang memiliki distribusi normal adalah 
MAP dan HR, sedangkan RR tidak berdistribusi normal.

\section{Tabel 6}

Uji Paired Samples Test

\begin{tabular}{cl}
\hline & Sig \\
\hline MAP pre dan Post & .000 \\
\hline Trans_HR pre dan post & .000 \\
\hline
\end{tabular}

Tabel 7

\section{Uji Wilcoxon}

\begin{tabular}{cc}
\hline & Sig \\
\hline RR Post HD- RR Pre HD & .000 \\
\hline Berdasarkan data & diatas
\end{tabular}

diperoleh nilai sig. (2-tailed) $\mathrm{p}<0,05$, sehingga dapat dikatakan bahwa ada perbedaan status hemodinamika pada pasien yang menjalani terapi hemodialisa.

\section{PEMBAHASAN}

Menurut Smeltzer dan Bare (2002), laki-laki lebih banyak memiliki kebiasaan yang dapat mempengaruhi kesehatan seperti merokok, minum kopi, alkohol dan minuman suplemen yang dapat memicu terjadinya peningkatan tekanan darah maupun banyaknya kandungan kafein di dalam ginjal sehingga menimbulkan penyakit sistemik yang dapat menyebabkan penurunan fungsi ginjal. Sedangkan menurut Price S.A \& Wilson L.M (2006), secara keseluruhan insidensi ESRD (End Stage Renal Disease) lebih besar pada laki- laki $(56,3 \%)$ daipada perempuan $(43,7 \%) \quad$ walaupum penyakit sistemik tertentu yang menyebabkan ESRD (seperti diabetes mellitus tipe 2 dan SLE) lebih sering terjadi pada wanita.

Menurut Tamher (2010), menjelaskan bahwa setelah melewati masa dewasa sel - sel jaringan tubuh mulai menua. Proses yang bersangkutan akan mengalami proses penuaan yang lebih cepat lagi sehingga secara keseluruhan fungsi tubuh akan berkurang. Pada lansia terjadi penurunan nefron sebesar $5-7 \%$ setiap dekade mulai usia 25 tahun. Mengakibatan bersihan kreatinin menurun dan berkurangnya kemampuan ginjal. Penyakit ginjal kronis memerlukan terapi pengganti ginjal salah satunya hemodialisis. Proses hemodialisis pada umumnya memerlukan waktu selama 4-5 jam. Salah satu komponen yang digunakan dalam proses hemodialisis yakni dialisat. Dialisat merupakan cairan yang membantu mengeluarkan sampah uremik dan juga dapat menggantikan substansi yang dibutuhkan tubuh seperti natrium. Sistem delivery dialisat dapat mengatur kadar natrium dialisat selama tindakan hemodialisis. Kadar natrium dialisat diubah sesuai dengan peresepan dari dokter. Hal ini disebut natrium modelling. Meskipun demikian, penggunaan natrium modelling juga meningkatkan rasa haus dan berat badan serta hipertensi diantara tindakan hemodialisis (Cahyaningsih, 2011).

Menurut Smeltzer \& Bare (2002), bila kadar natrium lebih rendah maka resiko terjadinya gangguan hemodinamik selama hemodialisis akan bertambah. Sedangkan bila kadar natrium lebih tinggi gangguan hemodinamik akan berkurang tetapi akan meningkatkan kadar natrium darah pasca dialisis.

Menurut Suharyanto \& Madjid (2009), dalam proses hemodialisa terjadi perubahan kadar elektrolit. Perubahan ini dimulai ketika darah yang mengandung natrium dan kalium dengan konsentrasi tinggi dilewatkan pada membrane semipermiabel yang terdapat dalam mesin dialiser. Dalam proses difusi, sisa- sisa metabolisme 
seperti natrium dan kalium dapat disaring sehingga kadar kalium dan natrium menurun. Selaput semipermiabel dapat dilewati oleh molekul dengan ukuran tertentu. Zat dengan berat molekul yang terdapat pada dialisat akan dapat dengan mudah berdifusi kedalam darah selama proses dialisis. Molekul ukuran kecil seperti kalium dan natrium maupun air dapat dengan mudah melewati selaput membrane ini melalui teknik osmosis. Setelah darah dicuci dalam dialiser selanjutnya darah yang bersih dialirkan kembali ke tubuh pasien melalui venous line sehingga proses ini dapat membuang kelebihan elektrolit dalam tubuh seperti natrium dan kalium. Hal tersebut akan berdampak pada hemodinamik seperti tekanan darah menjadi naik atau turun, nadi akan menjadi normal, maupun dapat mengurangi sesak napas pasien.

Hipertensi intradialitik adalah suatu kondisi berupa terjadinya peningkatan tekanan darah yang menetap pada saat HD dan tekanan darah selama dan pada saat akhir dari HD lebih tinggi dari tekanan darah saat memulai HD. Mekanisme terjadinya HID pada penderita dengan HD reguler sampai saat ini belum sepenuhnya diketahui. Banyak faktor yang diduga sebagai penyebab HID seperti aktivasi sistem renin angiotensin aldosteron system (RAAS) karena diinduksi oleh hipovolemia saat dilakukan ultrafiltrasi (UF), overaktif dari simpatis, variasi dari ion $\mathrm{K}+$ dan $\mathrm{Ca} 2+$ saat $\mathrm{HD}$, viskositas darah yang meningkat karena diinduksi oleh terapi eritropoeitin (EPO), fluid overload, peningkatan cardiac output (COP), obat antihipertensi yang ditarik saat HD dan vasokonstriksi yang diinduksi oleh endothelin-1 (ET-1). Di antara berbagai faktor tersebut yang paling umum diketahui sebagai penyebab HID adalah stimulasi RAAS oleh hipovolemia yang disebabkan oleh UF yang berlebihan saat HD dan variasi dari kadar elektrolit terutama kalsium dan kalium (Chazot \& Jean, 2010).

\section{KESIMPULAN DAN SARAN}

Ada perubahan hemodinamika pada pasien yang dilakukan terapi hemodialisa yang dibuktikan dengan uji Paired sample t-test utuk indikator sistolik, MAP (Mean Arterial Pressure), dan HR (Heart Rate) dengan nilai $\mathrm{p}<0,05$. Indikator Diastolik dan RR (Respiratory Rate) menggunakan uji wilcoxon dengan nilai $\mathrm{p}<0,05$. Saran untuk penelitian ini adalah bagi peneliti selanjutnya diharapkan dapat melakukan penelitian yang lebih kompleks dalam variabel, jumlah sampel maupun metode penelitian yang digunakan. Pada penelitian ini peneliti hanya menggunakan 4 indikator hemodinamika, diharapakan untuk penelitian selanjutnya dapat meneliti indikator- indikator lain dari hemodinamika.

\section{DAFTAR RUJUKAN}

Cahyaningsih. (2011). Hemodialisis (Cuci Darah) Panduan Praktis Perawatan Gagal Ginjal. Yogyakarta : Mitra Cendikia Press

Chazot C \& Jean G. (2010). Physiological changes during hemodialysis in patients with intradialysis hypertension. 69, 1833-1838.

Grassman, A., Gioberge, S., Moeller, S., \& Brown, G. (2005). ESRD Patients in 2004: Global Overview of Patient Numbers, Treatment Modalities and 
Associated

(http://www.oxfordjournals.org/ cgi/content/full/20/12/25 87). Diakses tanggal 30 Desember 2015

Hidayat A. Aziz Alimul \& Musrifatul. (2014). Ketrampilan Dasar Praktek Klinik. Jakarta : Salemba Medika

IRR (Indonesian Renal Registry). (2013). Simposium Dialisis. (online).

(www.indonesianrenalregistry.o rg, diakses 29 Maret 2016).

Jevon P \& Beverley Ewens. (2009). Pemantauan Pasien Kritis. Jakarta : Penerbit Erlangga

Nursalam. (2014). Metodologi Penelitian Ilmu Keperawatan Pendekatan Praktis. Jakarta : Salemba Medika. (2009). Metodologi Penelitian Ilmu Keperawatan Pendekatan Praktis Edisi 2. Jakarta : Salemba Medika

Potter P.A \& Anne G.P. (2006). Buku Ajar Fundamental Keperawatan Konsep, Proses, dan Praktik. Jakarta : EGC

Price S.A \& Wilson L.M. (2005). Patofisiologi : Konsep Klinis Proses- Proses Penyakit. Edisi 6. : Jakarta : EGC

Smeltzer, S. C. \& Bare, B. G. (2002). Buku Ajar Keperawatan Medikal Bedah. Jakarta: EGC.

Sudoyo Aru, dkk. (2009). Buku Ajar Ilmu Penyakit Dalam Jilid II Edisi $V$. Jakarta : Interna Publishing

Suharyanto T. \& Madjid A. (2009). Asuhan Keperawatan Pada Klien Dengan Gangguan Sistem Perkemihan. Jakarta : Trans Info Media
Sukandar. (2006). Gagal Ginjal. Jakarta : Rineka Cipta Sundara Y.T. (2014). Penyakit Di Indonesia, Sampai Dimana?. http://ppibelanda.org/penyakitginjal-di-indonesia-sampai-dimana/, diakses 20 Desember 2015 